\title{
Research with premature infant livers touches a nerve
}

Most stem cell researchers are accustomed to their work being greeted with controversy. But Lola Reid's work is so contentious even those in the field call her a scientific maverick.

Reid, a researcher at the University of North Carolina, is trying to isolate stem cells from the livers of premature infants who have died. The university was wary about her proposal, but after five years of meetings and reviews, in 2002, it granted her permission to proceed.

Reid says infant livers contain a higher concentration of fast-growing progenitor cells than adult livers. But her data are as yet unpublished and she is just moving into animal studies.

Many scientists are skeptical of Reid's work, but those interviewed for this story did not wish to be identified. Reid says it is only natural that the scientists are cautious. "They can wait until we publish all this," she says. "I'm just trying to give them a heads-up that this is a new direction to go in."

Reid's program is the first of its kind in the US. Premature babies are generally too small and underdeveloped to qualify as either donors or recipients of organs. Not surprisingly, Reid and her colleagues have found that the project is fraught with challenges and ethical dilemmas.

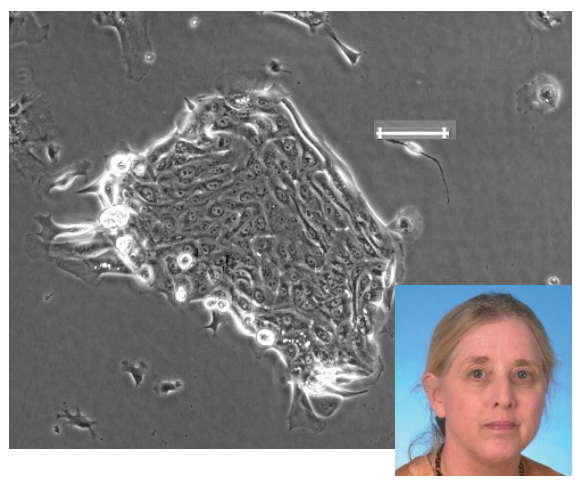

Lola Reid (inset) says infant livers are a superior source of stem cells.

In some cases, families must be approached for the organs only hours after the mother has given birth and many devastated parents decline. The researchers enlisted the help of a local agency that asks families for adult organs.

The university's bioethicists helped word the consent form to specify that the organs would be used for research, and not for transplantation or therapy. The document also informs donors that the liver cells might benefit Vesta Therapeutics, a company Reid helped create to develop stem cell-based liver treatments.

During the past two years, Reid has collected about 12 neonate livers and says her team has been able to harvest cells from the livers seven to eight hours after death. She says the organs are thick with hepatic progenitor cells and the cells grow more rapidly than those harvested from adult livers.

One prominent stem cell researcher, who asked not to be named, says it is too early to predict whether the cells will offer any advantage over adult cells. Another says it is unclear whether Reid's findings will hold up when she moves into in vivo tests. But some researchers are cautiously optimistic that she might be on to something.

"It is clearly true that the therapeutic use of these cells is completely unknown at this time," says Marcus Grompe, a hepatic stem cell researcher at Oregon Health \& Science University. "But their proliferative capacity and the fact that they survive so long after death make them very interesting candidates," he says. Grompe says he supports the science behind Reid's work, but "the emphasis should be on science, not application.”

Tinker Ready, Boston

\section{London calling for British medical research institute}

After months of deliberation, a task force set up to consider the future of the National Institute for Medical Research (NIMR)—one of Britain's leading centres for basic medical research-has recommended that the institute be moved from Mill Hill, on the outskirts of London, to a single site in central London.

"I am very happy that the decision is to retain the institute in London on a single site," says Robin Lovell-Badge, one of two NIMR researchers on the task force. "Any other option would probably have meant that the institute would not survive."

The Medical Research Council (MRC) has wanted to push the institute more toward clinical research and for the past year has been considering different options, including moving the institute closer to a research hospital (Nature 423, 573; 2003). NIMR staff have looked on anxiously as, over the course of several meetings, the task force considered the possibility of splitting the institute.

At the panel's last meeting in June, it ruled out several other choices, including the fragmentation option, and agreed unanimously that a single, more central location would best serve the institute's aim of translational research.
The new location would move the NIMR close either to King's College London or to University College London, both of which have expressed an interest in forming partnerships with it. The MRC will meet on July 29 to consider the panel's recommendation before it makes its decision.

The council will have to consider many factors such as cost and location, says Colin Blakemore, MRC chief executive and the panel's chair. "The task force has been relatively detached from issues like cost and how the decision fits with the general strategies of the research councils," he says.

"There is a general policy to move things out of London if possible," Blakemore adds. "The council has already said, from looking at our preliminary reports, that it is surprised by the central London recommendation."

The council might let the institute remain in its present site, he says. But an independent report commissioned by the MRC earlier this year found that the building, built in the 1930s, will need major refurbishment in 10-20 years.
For more news and analysis go to news@nature.com www.nature.com/news 